\title{
Antimicrobial action of calcium hydroxide-based endodontic sealers after setting, against E. faecalis biofilm
}

\section{Gabriely Cristinni REZENDE(a) Loiane MASSUNARI(a) India Olinta de Azevedo QUEIROZ(a) João Eduardo GOMES FILHO(a) Rogério Castilho JACINTO(a) Carolina Simonetti LODI ${ }^{(b)}$ Elói DEZAN JUNIOR ${ }^{(a)}$}

(a) Univ. Estadual Paulista - UNESP, Araçatuba School of Dentistry, Department of Endodontics, Araçatuba, SP, Brazil.

(b) Univ. Estadual Paulista - UNESP, Araçatuba School of Dentistry, Department of Pediatric Dentistry, Araçatuba, SP, Brazil.

Declaration of Interests: The authors certify that they have no commercial or associative interest that represents a conflict of interest in connection with the manuscript.

\section{Corresponding Author:}

Elói Dezan Junior

E-mail:dezan@foa.unesp.br

DOI: 10.1590/1807-3107BOR-2016.vol30.0038

Submitted: Aug 31, 2015

Accepted for publication: Oct 27, 2015

Last revision: Dec 03, 2015

\begin{abstract}
Enterococcus faecalis are gram positive bacteria that can mostly resist endodontic therapy, inducing persistent infection in the root canal system. Endodontic sealers with antimicrobial activity may help eliminate residual microorganisms that survive endodontic treatment. The present study aimed at comparing the antimicrobial activity of Acroseal, Sealapex and AH Plus endodontic sealers in an in vitro biofilm model. Bovine dentin specimens (144) were prepared, and twelve blocks for each sealer and each experimental time point (2, 7 and 14 days) were placed and left in contact with plates containing inoculum of $E$. faecalis (ATCC 51299), to induce biofilm formation. After 14 days, the samples were transferred to another plate with test sealers and kept at $37^{\circ} \mathrm{C}$ and $5 \% \mathrm{CO}_{2}$ for 2, 7 and 14 days. The specimens without sealers were used as a control for each period. The samples were agitated in a sonicator after each experiment. The suspensions were agitated in a vortex mixer, serially diluted in saline, and triple plated onto m-Enterococcus agar. Colonyforming units were counted, and the data were statistically analyzed using ANOVA, Shapiro-Wilk and Kruskal-Wallis one-way tests $(\mathrm{p}<0.05)$ to determine antimicrobial potential. Sealapex showed significant differences at all the experimental time points, in comparison with all the other groups. AH Plus and Acroseal showed antimicrobial activity only on the $14^{\text {th }}$ experimental day. Neither of the sealers tested were able to completely eliminate the biofilm. Sealapex showed the highest antimicrobial activity in all the experimental periods. The antimicrobial activity of all the sealers analyzed increased over time.
\end{abstract}

Keywords: Endodontics; Dental Cements; Biofilms; Enterococcus faecalis.

\section{Introduction}

Endodontic therapy aims to eliminate microorganisms from the root canal system by shaping, irrigation, and dressing. However, microorganisms cannot be completely eliminated. ${ }^{1}$

Sundqvist et al. $^{2}$ related that $38 \%$ of failed root canal treatments were infected by Enterococcus faecalis. Gram positive cocci facultative anaerobes can overcome the challenges of survival within the root canal system, and resist very harsh environmental conditions, including extreme alkaline $\mathrm{pH}(11.5),{ }^{3}$ by invading and surviving within dentinal tubules, ${ }^{4}$ and enduring prolonged periods of starvation. ${ }^{5}$ E. faecalis is also able 
to form biofilms, thus becoming more resistant to phagocytosis, antibodies and antimicrobials than non-biofilmproducing organisms; 6 for these reasons, it is one of the most widely studied microorganisms in the field of endodontics.

The use of root canal filling materials with antibacterial activity collaborates to eliminate persistent microorganisms. ${ }^{7}$ Several types of endodontic sealers are commercially available, such as calcium hydroxide-based Acroseal and Sealapex, and epoxy resin-based AH Plus. ${ }^{8}$ Sealapex and Acroseal are sealers containing calcium hydroxide, and their dissociation into calcium and hydroxyl ions alkalinize the environment, leaving it unfavorable to bacterial proliferation. ${ }^{1}$ Moreover, calcium ions can react with carbon dioxide and reduce the breathing source of anaerobic bacteria. ${ }^{9}$

AH Plus is a sealer with antimicrobial activity against $F$. nucleatum, $P$. gingivalis, ${ }^{10}$ and E. faecalis. ${ }^{11}$ Acroseal has also proved effective against $E$. faecalis by forming a zone of inhibition of microbial growth. ${ }^{12}$ However, according to the manufacturer's information, its original formula was modified (glycyrrhetic acid was replaced by TCD-diamide), leading to possible changes in its antimicrobial properties. Therefore it is essential to establish whether its new formulation has retained its antimicrobial properties.

Some methodologies have been used to evaluate the antimicrobial action of endodontic filling materials. Most of these methodologies have used a planktonic microorganism to test the antimicrobial activity of the sealers. ${ }^{11,13,14,15,16,17,18}$ However, the biofilm model is more appropriate, because microorganisms have greater resistance against the antimicrobial activity of the materials when they are organized into a biofilm. ${ }^{15}$ Therefore, the aim of the present study was to evaluate the in vitro antibacterial activity of 3 root canal filling materials (Acroseal, AH Plus and Sealapex), using a direct contact test against $E$. faecalis biofilm.

\section{Methodology}

\section{Sealer samples}

The sealers used in the present study were Acroseal (Septodont, Saint-Maur-des-Fossés, France), Sealapex
(Sybron Kerr Co., Romulus, USA) and AH Plus (Dentsply DeTrey GmbH, Konstanz, Germany). Sealer samples were made by manipulating and inserting the sealers to be tested into sterile silicone molds measuring $7 \mathrm{~mm} \times 1 \mathrm{~mm}$ (internal diameter $x$ thickness) in a laminar flow chamber (Veco Bioseg 12 Ltda., Campinas, Brazil). Specimens were kept at $37^{\circ} \mathrm{C}$ in controlled humidity for 56 hours. The sealers (Acroseal, Sealapex, and AH Plus) were prepared according to the manufacturers' recommendations.

\section{Analysis of antibiofilm activity}

Bovine incisors with completely formed roots were used as a substrate for biofilm development. The roots were sectioned into blocks measuring $4.0 \mathrm{~mm} \times 4.0 \mathrm{~mm} \times 1.5 \mathrm{~mm}$ (width $\times$ length $\times$ thickness) using a diamond disc at low speed, under abundant irrigation. The resulting blocks were immersed in $17 \%$ EDTA for $3 \mathrm{~min}$ to remove the smear layer, and then placed in a test tube containing distilled water and sterilized by autoclaving at $121^{\circ} \mathrm{C}$ for 20 minutes.

The microbiological procedures and manipulation of the sterilized dentine blocks were carried out in a laminar flow chamber (Veco Bioseg 12 Ltda., Campinas, Brazil). A standard strain of $E$. faecalis (ATCC 51299) was used for biofilm formation. The microorganism was reactivated in $20 \mathrm{~mL}$ sterile Brain Heart Infusion (BHI) Agar (Difco Laboratories Inc., Detroit, USA) and kept at $37^{\circ} \mathrm{C}$ for 24 hours. The colony was inoculated into $5.0 \mathrm{~mL}$ sterile brain heart infusion broth (Difco Laboratories Inc., Detroit, USA) and kept at $37^{\circ} \mathrm{C}$ overnight, after which the medium optical density was measured with a spectrophotometer (BioTek Instruments, Winooski, USA) set at $550 \mathrm{~nm}$ wavelength. The optical density was adjusted to 0.06 [approximately $9 \times 10^{7}$ colony-forming units per $\left.\mathrm{mL}\left(\mathrm{CFU} / \mathrm{mL}^{-1}\right)\right]$.

The bovine dentine blocks were placed in 24-well cell culture plates and each well received $200 \mu \mathrm{L}$ of adjusted inoculum plus $1.8 \mathrm{~mL}$ of sterile BHI medium. The cell culture plates with the submerged bovine dentine blocks were kept in $5 \% \mathrm{CO}_{2}$ (Ultra Safe, HF212-UV) at $37^{\circ} \mathrm{C}$ for 14 days. ${ }^{19,20}$ The BHI medium of each specimen was completely changed every $48 \mathrm{~h}$ without adding new microorganisms. 
Each endodontic sealer sample was removed from the mold and positioned over one of the dentine blocks containing biofilm. The dentine blocks/material samples were placed in new 24-well cell culture plates and kept in $5 \% \mathrm{CO}_{2}$ for 2,7 and 14 days at $37^{\circ} \mathrm{C}$. Twelve discs of each root canal sealer were used for each period of contact. Twelve dentin blocks with formed biofilm that was not placed in contact with any endodontic sealer discs were used as negative controls for each period of evaluation. Pilot studies have shown that dentine block/material samples have to be hydrated with $20 \mu \mathrm{L}$ of saline every day to simulate the root canal environment as well as possible.

After the respective contact periods elapsed, the endodontic sealer discs were removed, and the dentine blocks containing the remaining biofilm, including those belonging to the control group, were stored individually in test tubes containing $1 \mathrm{~mL}$ of sterile saline. The tubes were agitated with a sonicator (Misonix Inc., Fransingdale, USA) for $30 \mathrm{~s}$ at $40 \mathrm{~W}$ to disrupt the biofilm.

The suspensions of $E$. faecalis were serial diluted, and $10 \mu \mathrm{L}$ aliquots of each suspension were used for inoculation in Petri dishes containing m-Enterococcus agar medium (Acumedia, Neogen Corp., Lansing, USA); the dishes were then incubated in $5 \% \mathrm{CO}_{2}$ at $37^{\circ} \mathrm{C}$ for $48 \mathrm{~h}$ in triplicate. The readings for each Petri dish were performed on areas of bacterial growth, where the dilutions generated were between 3 and 30 colonies. The number of CFU/ $\mathrm{mL}^{-1}$ was calculated for each group, and the data were presented as the mean and standard deviation of the twelve specimens in each group.

\section{Statistical Analysis}

Statistical analysis was performed using Sigma Plot 12.0 (Systat Software Inc., San Jose, USA). The median minimum and maximum for the parameter measured (CFUs in the biofilm) were calculated for each group. The data were analyzed using a single-factor ANOVA model and Shapiro-Wilk, since they were not distributed normally, and the variances were not equal. The Kruskal-Wallis one-way test was also used. The level of significance was set at $5 \%$.

\section{Results}

Table 1 shows the mean CFU/mL $\mathrm{mL}^{-1}$ after 2, 7 and 14 days of biofilm contact with sealers. Comparison between the materials revealed that Sealapex reduced E. faecalis in 7 days and 14 days, as compared to 2 days $(\mathrm{p}<0.05)$. AH Plus and Acroseal reduced the CFU count just after 14 days, as compared with the control group. Comparison between periods revealed that all the sealers evaluated reduced E. faecalis CFU on the $14^{\text {th }}$ day in direct contact. E. faecalis in biofilm was not completely eliminated, regardless of the sealer used or the time point.

\section{Discussion}

All the sealers tested showed antimicrobial activity against biofilm after 14 days of direct contact, but Sealapex showed the best results. The antibacterial activity of sealers could help eliminate the residual microorganisms that survive after endodontic treatment, thus increasing the chances of success. ${ }^{7}$ The aim of this study was to evaluate the antibacterial activity of three endodontic sealers, using a direct contact test with the biofilm against $E$. faecalis, in periods of 2, 7, and 14 days. Although the antimicrobial activity of sealers has been used to evaluate the Agar

Table 1. Mean and standard deviation of CFU $\left(\mathrm{CFU} / \mathrm{ml}^{-1}\right)$ in the different groups and periods.

\begin{tabular}{|c|c|c|c|c|}
\hline \multirow{2}{*}{ Day } & \multicolumn{4}{|c|}{ Group (n=12) } \\
\hline & Acroseal & AHplus & Sealapex & Negative Control \\
\hline 2 & $7.7 \times 10^{6}\left( \pm 7.4 \times 10^{6}\right)^{\mathrm{A}, a}$ & $1.1 \times 10^{7}\left( \pm 1.0 \times 10^{7}\right)^{\mathrm{A}, \mathrm{a}}$ & $5.8 \times 10^{5}\left( \pm 5.0 \times 10^{5}\right)^{\mathrm{B}, a}$ & $1.3 \times 10^{7}\left( \pm 1.3 \times 10^{7}\right)^{\mathrm{A}, \mathrm{a}}$ \\
\hline 7 & $4.0 \times 10^{6}\left( \pm 3.5 \times 10^{6}\right)^{A, a}$ & $5.0 \times 10^{6}\left( \pm 3.7 \times 10^{6}\right)^{A, a}$ & $1.3 \times 10^{4}\left( \pm 1.1 \times 10^{4}\right)^{8, b}$ & $1.1 \times 10^{7}\left( \pm 1.1 \times 10^{7}\right)^{\mathrm{A}, \mathrm{a}}$ \\
\hline 14 & $9.2 \times 10^{5}\left( \pm 9.6 \times 10^{5}\right)^{\mathrm{A}, 6}$ & $7.1 \times 10^{5}\left( \pm 7.9 \times 10^{5}\right)^{\mathrm{A}, \mathrm{b}}$ & $3.6 \times 10^{1}\left( \pm 8.4 \times 10^{1}\right)^{\mathrm{B}, \mathrm{C}}$ & $1.2 \times 10^{7}\left( \pm 1.6 \times 10^{7}\right)^{\mathrm{C}, \mathrm{a}}$ \\
\hline
\end{tabular}

Kruskal-Wallis one-way $(p<0.05)$.

Different uppercase letters indicate a statistical difference $(p<0.05)$ among the groups

Different lowercase letters indicate a statistical difference $(p<0.05)$ among the time periods. 
Diffusion Test, this test is relatively insensitive, and the results are dependent on the diffusion and physical properties of the tested materials. ${ }^{21}$ The Direct Contact Test (DCT) was chosen in the present study, because it was designed to overcome these limitations, to enable assessment of the in vitro antibacterial activities of numerous endodontic sealers. ${ }^{19,20,22}$ Moreover, direct contact with the biofilm grown on dentin blocks avoids false positives attributed to physical entombment of bacteria in root canals and dentinal tubules.

In this research, E. faecalis was allowed to grow over bovine dentine blocks for 14 days to form biofilm, following the method described by Faria-Júnior et al. ${ }^{19}$ Previous studies have used different biofilm induction periods. ${ }^{11,20,23}$ However, it has been shown that biofilms formed in the first few days of incubation may not display the same antimicrobial resistance of a mature biofilm. ${ }^{24,25}$ According to Guerreiro-Tanomaru et al., ${ }^{20}$ the percentage of biofilm surface coverage on bovine dentine blocks was higher at 14 days than at 21 days, with no statistical differences between the two periods, thus justifying the 14 day-incubation period used in the present research.

In the present study, Sealapex antimicrobial activity increased over time, and was significantly higher than that of Acroseal and AH Plus. Sealapex is a calcium hydroxide-based sealer that showed excellent antimicrobial activity in periods of $24 \mathrm{~h}$, $48 \mathrm{~h}, 72 \mathrm{~h}$ and 7 days by agar diffusion. . $^{1314,15,16,21}$ Similar results were found by Faria-Júnior et al. ${ }^{19}$ using DCT against E. faecalis biofilm. Heyder et al. ${ }^{11}$ evaluated the antimicrobial action of several sealers and found that $E$. faecalis was influenced by Sealapex at $24 \mathrm{~h}$, and Zhang et al. ${ }^{7}$ reported that Sealapex had the strongest antimicrobial effect against $E$. faecalis after 7 days. The ionization may account for the antimicrobial activity of Sealapex, which releases hydroxyl ions, thus increasing the $\mathrm{pH}$ and leaving the environment unfavorable for microorganism growth. ${ }^{26}$ Schäfer et al. ${ }^{27}$ showed that Sealapex was significantly more soluble in water than AH Plus, which can explain the antimicrobial action of Sealapex after 2 days.

Acroseal also is a calcium hydroxide-based sealer, but in the present study it showed no antimicrobial activity against $E$. faecalis in 2 and 7 days, only after 14 days. Pinheiro et al. ${ }^{12}$ related that Acroseal sealer was effective against $E$. faecalis at $48 \mathrm{~h}$, disagreeing with the results of the present study; this can be explained by the differences in methodologies. The antimicrobial activity of hydroxide-based sealers may be caused by the release of hydroxyl ions, thus making the medium alkaline. However, Acroseal showed the least amount of calcium and hydroxyl ion release, due to the relative insolubility of its compounds. ${ }^{9}$ The low solubility of Acroseal can explain its difference from Sealapex ${ }^{28}$ although both are hydroxide-based sealers, and showed late antimicrobial activity, suggesting that Acroseal needs a longer time to release hydroxyl ions.

In the present study, no antimicrobial activity was found for AH Plus after 2 and 7 days of DCT; these results agree with those of others studies., ${ }^{1,29}$ Poggio et al. ${ }^{17}$ used ADT with freshly mixed endodontic sealer (Endomethasone C, Argoseal, Bioseal Normal, Acroseal, AH Plus, Sicura Seal) after 24 and 48 h, and found low antibacterial activity for AH Plus in the periods tested. Wang et al. ${ }^{23}$ evaluated the proportions of dead and live bacteria inside the dentinal tubules after exposure to root canal sealers by confocal laser scanning microscopy, and reported antimicrobial activity for AH Plus after 1 and 7 days, unlike the results of the present study, which found no antimicrobial activity after 7 days. This difference may be explained by the fact that the sealers used in the present study were not fresh when put into contact with the biofilm, whereas the antimicrobial activity of test sealers depends on the time interval between mixing and testing..$^{29}$ In the present study, the sealers were put into contact with biofilm just $56 \mathrm{~h}$ after manipulation, whereas Wang et al. ${ }^{23}$ and Poggio et al. ${ }^{17}$ used the sealer freshly manipulated. Studies report that the antimicrobial action of $\mathrm{AH}$ Plus is attributed to formaldehyde release over a short period of time during the setting time. ${ }^{7,26,30}$ However, just after 14 days, AH Plus showed antimicrobial effectiveness against $E$. faecalis in the present study, disagreeing with Slutzky-Goldberg et al., ${ }^{31}$ who did not find any antimicrobial action after 14 days. The different methodologies used can explain the variation in results. As reported in recent studies, the late antimicrobial activity of AH Plus may be attributed to the lower solubility of this sealer, which 
discourages the $\mathrm{pH}$ from becoming alkaline and the release of calcium ions. ${ }^{32}$

This study also showed that time is an important factor in influencing the antimicrobial sealer action. All sealers showed some antimicrobial activity in direct contact, compared with the control group, but only Sealapex showed significant antimicrobial action. After 14 days, Acroseal and AH Plus started to have antimicrobial action, but it was less effective than that of Sealapex.

\section{References}

1. Mickel AK, Nguyen TH, Chogle S. Antimicrobial activity of endodontic sealers on Enterococcus faecalis. J Endod. 2003;29(4):257-8. doi:10.1097/00004770-200304000-00006

2. Sundqvist G, Figdor D, Persson S, Sjögren U. Microbiologic analysis of teeth with failed endodontic treatment and the outcome of conservative retreatment. Oral Surg Oral Med Oral Pathol. 1998;85(1):86-93. doi:10.1016/S1079-2104(98)90404-8

3. McHugh CP, Zhang P, Michalek S, Eleazer PD. pH required to kill Enterococcus faecalis in vitro. J Endod. 2004;30(4):218-9. doi:10.1097/00004770-200404000-00008

4. Love RM. Enterococcus faecalis: a mechanism for its role in endodontic failure. Int Endod J. 2001;34(5):399-405. doi:10.1046/j.1365-2591.2001.00437.x

5. Figdor D, Davies JK, Sundqvist G. Starvation survival, growth and recovery of Enterococcus faecalis in human serum. Oral Microbiol Immunol. 2003;18(4):234-9. doi:10.1034/j.1399-302X.2003.00072.x

6. Distel JW, Hatton JF, Gillespie MJ. Biofilm formation in medicated root canals. J Endod. 2002;28(10):689-93. doi:10.1097/00004770-200210000-00003

7. Zhang H, Shen Y, Ruse ND, Haapasalo M. Antibacterial activity of endodontic sealers by modified direct contact test against Enterococcus faecalis. J Endod. 2009;35(7):1051-5. doi:10.1016/j.joen.2009.04.022

8. Setya G, Nagpal A, Kumar S, Ingle NA. Comparison of root canal sealer distribution in obturated root canal: an in-vitro study. J Int Soc Prev Community Dent. 2014;4(3):193-7. doi:10.4103/2231-0762.142028

9. Eldeniz AU, Erdemir A, Kurtoglu F, Esener T. Evaluation of $\mathrm{pH}$ and calcium ion release of Acroseal sealer in comparison with Apexit and Sealapex sealers. Oral Surg Oral Med Oral Pathol Oral Radiol Endod. 2007;103(3):e86-91.

10. Siqueira Jr JF, Favieri A, Gahyva SMM, Moraes SR, Lima KC, Lopes HP. Antimicrobial activity and flow rate of newer and established root canal sealers. J Endod. 2000;26(5):274-7. doi:10.1097/00004770-200005000-00005

11. Heyder M, Kranz S, Völpel A, Pfister W, Watts DC, Jandt $K D$, et al. Antibacterial effect of different root canal sealers

\section{Conclusion}

Based on the results, it can be concluded that E. faecalis biofilm was not completely eliminated, regardless of the sealer used or the time period tested; AH Plus and Acroseal started displaying antimicrobial action just after 14 days; Sealapex showed higher antimicrobial activity against $E$. faecalis in all the time periods; and all the sealers presented higher antimicrobial activity over time.

on three bacterial species. Dent Mater. 2013;29(5):542-9. doi:10.1016/j.dental.2013.02.007

12. Pinheiro CR, Guinesi AS, Pizzolitto AC, Bonetti-Filho I. In vitro antimicrobial activity of Acroseal, Polifil and Epiphany against Enterococcus faecalis. Braz Dent J. 2009;20(2):107-11. doi:10.1590/S0103-64402009000200003

13. Aal-Saraj AB, Ariffin Z, Masudi SM. An agar diffusion study comparing the antimicrobial activity of Nanoseal with some other endodontic sealers. Aust Endod J. 2012;38(2):60-3. doi:10.1111/j.1747-4477.2010.00241.x

14. Bodrumlu E, Semiz M. Antibacterial activity of a new endodontic sealer against Enterococcus faecalis. J Can Dent Assoc. 2006;72(7):637.

15. Queiroz AM, Nelson-Filho P, Silva LA, Assed S, Silva RA, Ito IY. Antibacterial activity of root canal filling materials for primary teeth: zinc oxide and eugenol cement, Calen paste thickened with zinc oxide, Sealapex and EndoREZ. Braz Dent J. 2009;20(4):290-6. doi:10.1590/S0103-64402009000400005

16. Sipert CR, Hussne RP, Nishiyama CK, Torres SA. In vitro antimicrobial activity of Fill Canal, Sealapex, Mineral Trioxide Aggregate, Portland cement and EndoRez. Int Endod J. 2005;38(8):539-43. doi:10.1111/j.1365-2591.2005.00984.x

17. Poggio C, Lombardini M, Colombo M, Dagna A, Saino E, Arciola CR, et al. Antibacterial effects of six endodontic sealers. Int J Artif Organs. 2011;34(9):908-13. doi:10.5301/ijao.5000055

18. Kayaoglu G, Erten H, Alaçam T, Ørstavik D. Shortterm antibacterial activity of root canal sealers towards Enterococcus faecalis. Int Endod J. 2005;38(7):483-8. doi:10.1111/j.1365-2591.2005.00981.x

19. Faria-Júnior NB, Tanomaru-Filho $M$, Berbert FLCV, Guerreiro-Tanomaru JM. Antibiofilm activity, $\mathrm{pH}$ and solubility of endodontic sealers. Int Endod J. 2013;46(8):755-62. doi:10.1111/iej.12055

20. Guerreiro-Tanomaru JM, Faria-Júnior NB, Duarte MAH, Ordinola-Zapata R, Graeff MSZ, Tanomaru-Filho M. Comparative analysis of Enterococcus faecalis biofilm formation on different substrates. J Endod. 2013;39(3):346-50. doi:10.1016/j.joen.2012.09.027 
21. Tobias RS. Antibacterial properties of dental restorative materials: a review. Int J Endod. 1988;21(2):155-60. doi:10.1111/j.1365-2591.1988.tb00969.x

22. Weiss E, Shalhav M, Fuss Z. Assessment of antibacterial activity of endodontic sealers by a direct contact test. Endod Dent Traumatol. 1996;12(4):179-84. doi:10.1111/j.1600-9657.1996.tb00511.x

23. Wang Z, Shen Y, Haapasalo M. Dentin extends the antibacterial effect of endodontic sealers against Enterococcus faecalis biofilms. J Endod. 2014;40(4):505-8. doi:10.1016/j.joen.2013.10.042

24. Özok AR, Wu MK, Luppens SBI, Wesselink PR. Comparison of growth and susceptibility to sodium hypochlorite of mono- and dual-species biofilms of Fusobacterium nucleatum and Peptostreptococcus (micromonas) micros. J Endod. 2007;33(7):819-22. doi:10.1016/j.joen.2007.03.008

25. Sun J, Song X. Assessment of antimicrobial susceptibility of Enterococcus faecalis isolated from chronic periodontitis in biofilm versus planktonic phase. J Periodontol. 2011;82(4):626-31. doi:10.1902/jop.2010.100378

26. Leonardo MR, Silva LAB, Tanomaru Filho M, Bonifácio KC, Ito IY. In vitro evaluation of antimicrobial activity of sealers and pastes used in endodontics. J Endod. 2000;26(7):391-4. doi:10.1097/00004770-200007000-00003
27. Schäfer E, Zandbiglari T. Solubility of root-canal sealers in water and artificial saliva. Int Endod J. 2003;36(10):660-9. doi:10.1046/j.1365-2591.2003.00705.x

28. Marciano MA, Guimarães BM, Ordinola-Zapata R, Bramante CM, Cavenago BC, Garcia RB, et al. Physical properties and interfacial adaptation of three epoxy resin-based sealers. J Endod. 2011;37(10):1417-21. doi:10.1016/j.joen.2011.06.023

29. Pizzo G, Giammanco GM, Cumbo E, Nicolosi G, Gallina G. In vitro antibacterial activity of endodontic sealers. J Dent, 2006 Jan;34(1):35-40. doi:10.1016/j.jdent.2005.03.001

30. Cobankara FK, Altinöz HC, Ergani O, Kav K, Belli S. In vitro antibacterial activities of root-canal sealers by using two different methods. J Endod. 2004;30(1):57-60. doi:10.1097/00004770-200401000-00013

31. Slutzky-Goldberg I, Slutzky H, Solomonov M, Moshonov J, Weiss EI, Matalon S. Antibacterial properties of four endodontic sealers. J Endod. 2008;34(6):735-8. doi: 0.1016/j.joen.2008.03.012

32. Duarte MAH, Ordinola-Zapata R, Bernardes RA, Bramante CM, Bernardineli N, Garcia RB, et al. Influence of calcium hydroxide association on the physical properties of AH Plus. J Endod. 2010;36(6):1048-51. doi:10.1016/j.joen.2010.02.007 